\title{
THE HISTORY AND PRINCIPLES \\ OF AMERICAN PERSONALISM: \\ A COMPARISON OF THE HARVARD AND BOSTON UNIVERSITY SCHOOLS
}

\begin{abstract}
A bstract. The author of this article outlines the background of American personalist philosophy and theology, and then he traces these German roots through to the two primary schools of American personalist thought: the Boston University and the Harvard schools of personalism. Along the way he points to the major points on influence and divergence of the development of American personalism. He summarizes the principles of both schools as well as the views rejected, both philosophical and religious, by personalists.
\end{abstract}

Keywords: philosophy; theology; personalism; American personalist thought; German roots; the Boston University and the Harvard schools of personalism.

\section{INTRODUCTION}

Much work has been done to trace the development of the philosophy and theology of personalism from its rise in the late 18th century in Germany, to its maturation and flowering in a number of countries during the 19th and 20th centuries. Of special note are the histories written by Jan Olof Bengtsson, Albert C. Knudson, and Rufus Burrow, Jr. (See the Bibliography.) Much of what I will say here depends on their excellent work. Documentation of the various books, articles, and influences has been carried out by scholars in a number of countries. There are bibliographies and documented histories in various languages, including English, Spanish, Polish, Italian, Swedish, and French. The narrative I am offering here is

Prof. Dr. RANDALl AUXIER — Southern Illinois University (SIU), Carbondale, USA, Professor of Communication Studies and Philosophy; correspondence address: Southern Illinois University, Comm. Bldg, Room 2242, Carbondale, IL 62901, USA; e-mail: personalist61@gmail.com; ORCID: https://orcid.org/0000-0003-1121-1471. 
about two lines of influence and development that began in Germany and were exported to the United States. Not many people have fully understood these two lines in their inter-relation. There are a number of reasons why the lines of descent and development have not been well understood, and I will provide some of those reasons in the following essay. I will conclude with some considerations of the theological place of American personalism among the various Christian and other theologies of the world.

I must ask the reader to understand that my discussion will be of a general nature and invite anyone who wishes to examine these sources in detail, and, if necessary to dispute them wherever I might stray from an account that is uncontroversial. But in my decades of research in personalism (also noted in the bibliography), I have come to understand, in a larger way, the transmission and transformations of the philosophy of personalism in a way that not many people would have the opportunity to do. I will keep the narrative general, speaking mainly on my own authority, such as it is, and being content to invite correction if it is needed.

\section{GERMAN ORIGINS}

While the history of the idea of "person" and "persona" is important to any history of personalism, the needed facts and interpretations have been provided by numerous earlier writers. I recommend Bengtsson on this question, but I have nothing to add to the existing knowledge. In Germany, the idea that "person" should be taken as primary to ethical life comes from Kant. It is Kant who had the insight that the other person is sublime and cannot be cognized directly, in its essence, by any finite consciousness. Our efforts to treat the other person as the object a causal judgment, or of an aesthetic judgment fails. The basis of this failure is that three postulates, concepts of reason, are required for comprehension of the person, and these concepts cannot be apprehended: we must skip, imaginatively, to what the other person would be if we could understand him/her, and we must interact with that comprehended whole, which remains not only vague, but in fact, un-cognizable except by analogy, by way of the symbol. That symbol cannot be mistaken for what it symbolizes, and we must be content to bask in its beauty and morally laudable effects upon ourselves, in our subjectivity, and upon others.

The sublimity of the other person also confronts the causal order with a mode of limitation upon nature (the causal order) that cannot be exceeded 
by our reason except dialectically, a logic of the problematic, how what is actual affects what is possible. This kind of reasoning never reaches an end, for finite cognition. But might it reach an end by transcendence? This supposition became the basis for the argument that defined personalism after Kant. Some, such as J. G. Fichte, seemed to suggest that such an end might be within the cognitive powers of the finite thinker. Others, such as the young Schelling and Hegel, seemed to be pursuing this supposition toward a deification of the human soul, seeing the boundaries between human and divine as a difference of degree, of attainment, rather than of kind.

Against this view, which was labeled pantheism and connected to the philosophy and theology of Spinoza, came the first personalists, in the fullest sense. F. H. Jacobi wrote a famous open letter that proved influential, and which may or may not have had a direct influence on Schelling, who withdrew, over a decade, from the view he thus criticizes as pantheism, and went seriously to work on a revised view that historians now recognize as an important form of personalism. Ironically, in the generation following I. H. Fichte, we find fairly strong threads leading back to a more reserved reading of Kant, led by figures such as Goethe and the Schlegels, but also defended in technical detail by I. H. Fichte, the son of the philosopher vilified in the strife, but too young to remember it. Nevertheless, in a long life, I.H. Fichte opposed the Hegelian philosophy and defended a theistic version of personalism. At the same time, although Schelling retired from public life, the younger Fichte lived long enough to see the publication of Schelling's collected works, and together these two were seen as the most important voices of personalism during their generation.

After the death of Hegel, and against growing political turmoil in Europe, the conservative German academy went through a "back-to-Kant" movement, involving many fine minds in many ways at many universities. On the atheistic side, Schopenhauer lived long enough to see his efforts receive attention, but this was a profoundly impersonalist development of Kant. On the theistic and personalist side, the emerging voice was that of Rudolf Hermann Lotze (1817-1881). Lotze was trained in medicine, as well as philosophy. He was not well understood in his time, since he did not fit as either a complete enemy of Hegel, nor as a materialist. His effort was to build an empirical philosophy that was based on the person, physical, psychological, logical, and metaphysical, without reducing any of these fundamental divisions to the others. The approach left traditional theism intact without making it the explanation of everything humans know. This was a limitation Kant had advised, limiting reason to make room for faith. 
While Lotze is not much studied today, which is regrettable, his viewpoint remains by way of at least two of his American students, Borden Parker Bowne and Josiah Royce. Much else might be said about Lotze, but our present purpose is served if we note that these two pivotal figures studied with Lotze returned to the USA and exerted tremendous influence upon the development of philosophy in general and personalism in particular, both in the US and, by indirect paths, back to Europe.

At this stage of its development it was easier to say what personalism opposed than to explain what it favored. Having grown from a kind of strife, many personalists were clearer about what they opposed than about what the believed. Those positions rejected by philosophical personalists included:

- All versions of metaphysical materialism.

- Any form of naturalism that does not hold personality to be a fundamental feature of nature.

- Many Darwinian philosophies, although most personalists do embrace evolution in one way or another.

- Versions of absolute idealism in which the "Absolute" is seen as an impersonal being.

- Nearly all forms of philosophical and causal determinism; personalists hold that free activity of some sort is an indispensable precondition of personal being/existence.

- Most stoicism, all Spinozism, Hobbesian philosophy, the school of Herbert Spencer.

- Most varieties of scientific positivism, although most personalists are keen to develop science.

Learning to recognize the personalist view, in philosophy and theology, begins with a thorough understanding of what is rejected. The survey of why all of these positions are rejected is the negative side of the effort to articulate personalism itself, and it is no easy task. Personalists spend a good deal of effort trying to convince people to set aside these reductionist, dogmatic, hybristic, and nihilistic views. Yet, such views have a broad appeal that manages to survive and revive with every generation.

In addition to these philosophical issues, there are religious issues. For those who reject impersonalism for religious as well as philosophical reasons, we can add this list of positions that are rejected:

- Those versions of Calvinist and evangelical Christianity which lay such stress on the radical otherness of God as to deny explicitly or by implication the accessibility and attributes of God that would make 
God a personal being, or which would emphasize the fallen character of humanity to such a degree as to render personal existence itself an evil (extreme original sin that denies the efficacy of the cross).

- Some extreme forms of Islam similarly imply impersonalism, although they do not espouse it. Wherever God is utterly transcendent, God is impersonal.

- Some forms of Buddhism are impersonalist (although not in practice) in seeing the very existence of finite personality as the effect of a kind of desire that can be and should be overcome through following a path toward Enlightenment (personality is "attachment").

- Vēdic traditions of India hold an ambiguous place. Even those who deny that Brahman has a personal form of being may still be personalistic to an extent, in their articulation of the concept of "Atman," or the personal self. The issue is very complex.

The point is that personalists may come to the view for other than philosophical and dialectical reasons, but on the basis of faith. Jesus is a person, and so is God and the Holy Spirit. If this is true, then the complexity of "person" may be treated as a mystery without abdicating our philosophical responsibilities to know and understand. It is likely that most personalists, Christion, Jewish, Muslims, and followers of the Eastern traditions, are willing to embrace mystery at some level. No such expectation accompanies philosophical personalism. Obviously, a philosopher might also be religious, and hence, have extra motivation to defend personalism. Such commonly occurs, but it leads those who are not personalists into perplexities as to why the view is being defended, in some instances. It is thus incumbent upon personalists who wish to be understood clearly to know and make explicit the differences between their philosophical and religious reasons for taking on the view itself.

\section{THE BOSTON UNIVERSITY SCHOOL}

Borden Parker Bowne (1847-1910) was Josiah Royce's elder by eight years (1855-1916), and thus studied with Lotze sooner. Bowne studied philosophy in Europe from 1872 to 1874 at the Universities of Paris, Halle, and Göttingen. Lotze held the chair in philosophy at Göttingen during this time and became the principal influence on Bowne's philosophical thinking. Bowne returned to the US in 1875. In 1876, Bowne was called to the young 
and rising faculty of Boston University, where he taught in the College of Liberal Arts, the School of Theology, and served as the first dean of the Graduate School. Over the years, as he developed his ideas, he called his philosophy by a number of different names, including "transcendental empiricism," but in the end he settled upon "personalism," by about 1898 .

It is important to be aware that the philosophy of personalism, as espoused by Bowne, Royce, and others, was well-developed before it took on this label. In some ways, the confusion that is commonly met with among historians of philosophy and theology when one uses the label "personalism" derives from the inconvenient lateness of the appellation and its settling in to the general vocabulary of intellectuals. One must learn to recognize the view itself, without the label, to trace the philosophy of personalism. It is unhelpful that some of the most important voices in the development of personalism, such as Lotze, did not often use the term. But no one who studies his works can doubt for a moment that he was a personalist, a fact welldocumented by dozens of histories of personalism. Yet, that he was a personalist s missing, for example, from his English Wikipedia article.

Other important voices, such as Pope Leo XIII, did use some version of this label, and as a result, historians who look for such labels do find his ideas and will tend to conclude that all of personalism must be read through his influence. This is unfortunate, but understandable. The kind of personalism descending from Kant through Lotze to Bowne is distinctly protestant, and with a real tendency to individualism. It has the strengths associated with that view, especially in its applicability to modern democratic politics, but also the weaknesses that can befall an over-emphasis upon the individual. Subsequent philosophers in the Boston University School of personalism have found themselves obliged to compensate for the weaknesses grounded in its over-emphasis on the individual.

In a long career, Bowne had numerous influential students who took some version of personalism to various parts of North America. Ralph Tyler Flewelling went to southern California and established the most important journal of the movement, The Personalist. Albert C. Knudson and Francis John McConnell taught theological personalism and exercised great influence upon the Methodist Church, which was the denomination of Protestants (descending from the Church of England) that founded Boston University (and over 100 other colleges and universities in the US). The inheritor of the mantle from Bowne in philosophy was Edgar Sheffield Brightman (1878-1953), whose various students were to take the philosophy of personalism to many social and religious struggles, including Martin Luther King, Jr. 
The principles of Boston University personalism I formulate here in order to show both their comparison and contrast with Harvard University personalism, which I will outline next. The view stresses these principles (starting places for thought):

- The idea of person is the clue to the structure and meaning of the universe.

- Time and space are phenomenal, experienced by both God and humanity, but differently, allowing the development of the human person. Time is the moving picture of eternity.

- The meaning of the universe is by, of, and for persons.

- There are human, super-human, and sub-human persons.

- Practical life is the source of value and meaning in all life.

- Individual life, i.e., the "soul," is social, but is an ultimate value; the individual is the "person" in the most concrete and excellent sense.

- God, or the divine, is personal in as much as we can understand and respond to deity.

- The impersonal does not exist, but the degradation of personal existing is real, and thus the universe is tragic, even for God.

Each of these principles would require long explanations and elucidations, but that is beyond my present purpose. I have written elsewhere about these, and many others have done the same. We will see, how these views compare and contrast with those of the Harvard school of personalists.

\section{THE METAPHYSICAL CLUB}

William James described a group of intellectuals who met every two weeks for some dozen or more years in "Thomas Davidson's rooms in Temple Street" in Boston. These meetings began, it seems, around 1872, and this is the origin of "The Metaphysical Club," whose actual history has been much obscured by the loose work of various historians, especially Louis Menand, in a book which appropriated the name of the club, but with very little real investigation into its history and meaning. The group included, importantly, William James, Borden Parker Bowne, Charles Sanders Peirce (when he was in Boston), Chauncey Wright, and George Holmes Howison. Its membership changed over the years, but everyone agrees that Thomas Davidson was the soul of the group. Known as an Aristotelian individualist, and a person who believed ethics is First Philosophy, Davidson goaded his fellows to press their original ideas forward. 
All of these thinkers were personalists of some sort, although James was the only one (apart from Bowne) to call himself that explicitly. James's ringing endorsements of Bowne's metaphysics in The Principles of Psychology are often overlooked, but they should not be. James said in effect that if his Principles has a metaphysics, it is Bowne's. His endorsements continue throughout his career to the end, which is not to say he never had disagreements.

In 1884 , a new voice came into the discussion Davidson was having, and that was Josiah Royce. It is likely that James had included Royce earlier. Royce spent the summer of 1877 in Boston, basically reading whatever James told him to read, including Peirce's writings. But it seems Royce did not meet Peirce at this time, since Peirce was abroad. In any case, there is no doubt that a second personalist voice entered James' head at that time, since Royce was just back from studying with Lotze, and he made no secret of the influence Lotze exerted. Initially Royce was taken with Schopenhauer, however, and seems not to have come fully into his personalist sensibilities until about 1880, when he was teaching at Berkeley. Royce returned to Harvard permanently in 1884, and from there forward, James was between two of Lotze's students and struggling with many forms of the idea of personalist and personhood.

From this club, Howison would go on to form the northern California school of personalism, since he went to Berkeley at exactly the time Royce left. Between Flewelling in the south and Howison in the north, personalism took explicit hold of the developing intellectual life of California. In some ways it remains there. Peirce had, at some point, taken up personalism, although he did not call it that. Examining the revision of his "New List of Categories" in 1893 (originally published in 1867, see the two texts compared here: https://arisbe.sitehost.iu.edu/menu/library/bycsp/ms403/catego ries.htm), one can see Peirce adding the personalism into the work. He had met and argued with Royce in the summer of 1892, and so it may be that Royce's influence had an effect. In any case, the well-known Peirce scholar Douglas R. Anderson says:

It is often lamented by Peirce scholars that Peirce, as Bernstein says, "has failed to work out an adequate theory of the self" [4]. However, I believe the real failure here is that there is a tendency not to see what stares us in the face, as Peirce might have said. Peirce's entire philosophy is a theory of the self: God is a person, God is mind. The universe unfolds under the agapistic guidance of God. Creative evolution is, in being God's symbol, the development of a self. 
And so with finite beings. The descriptions of and norms for their behavior are everywhere; for Peirce's philosophy, as we saw, is at bottom anthropomorphic because phenomenologically that is all we have as evidence. ${ }^{1}$

Since Peirce is easily the most important philosopher in this story, apart from Kant, it is crucial that we grasp he was a personalist, and that he knew he was, even though the label did not exist. Yet, the vast literature on Peirce is written by people who do not know what personalism is or how to recognize it when it is "staring them in the face." Thus, one may meet resistance if one simply asserts Peirce's personalism. A longer account must be given, which I hope to provide in the future. But when one reads Peirce and knows what makes for a thorough-going personalist, one cannot seriously doubt the aptness of the label. Yet, it is also clear that it was a view that developed in his thought after 1867, and perhaps due to discussions with the Metaphysical Club, perhaps reinforced by the close contact with Royce during 1892.

Joining Peirce was James, who seems to have been a personalist from his earliest philosophical writings, and the most obvious source for the view was Bowne. In describing his philosophy as a whole, James said:

It means individualism, personalism: that the prototype of reality is the here \& now; that there is genuine novelty; that order is being wonincidentally reaped. that the more universal is the more abstract[;] that the smaller \& more intimate is the truer. The man more than the home, the home more than the state, or the church. Anti-slavery. It means tolerance and respect. ${ }^{2}$

By the time he said this James had also come under the influence of Charles Renouvier, whose book on personalism had affected him greatly. I have explained the sources and development of James's personalism in detail elsewhere, but it moved in concert with Bowne's view for the most part. Renouvier tilted James a bit toward the pan-experientialist side, but reinforced his developing idea that "person" is the principle of individuation, and in this latter sense, he was more radical than Bowne, and positively opposed to Royce's communitarian personalism.

\footnotetext{
${ }^{1}$ Douglas R. Anderson, Creativity and the Philosophy of C.S. Peirce (Dordrecht: Springer, 1987), 152.

${ }^{2}$ William James. Manuscript Lectures, ed. Ignas K. Skrupskelis (Cambridge, MA / London, England: Harvard University Press, 1998), 311.
} 
The third personalist in the Harvard triad was Royce, whose personalism came not from the Metaphysical Club or Bowne, but from Lotze. Royce studied with Lotze in 1876, but it seems to have taken him a year or so afterwards to emerge as a personalist in any clear way, and that was perhaps in part due to James's influence on him, both in Baltimore and Cambridge in 1877. In any case, this development has been treated in detail by me and by other writers, and the form of his personalism is well described elsewhere. For the present, the point is that there were three important personalist voices dominating Harvard from 1890 until Royce died in 1916. As teachers, these three influenced several generations of other philosophers in the direction of personalism. The most important names are William Ernest Hocking, W. E. B. Du Bois, Charles Hartshorne, and Gabriel Marcel (who took Royce's and Hocking's personalism back to Europe). Royce and James also influenced Husserl in a personalist direction, which may account for the personalistic aspects of many subsequent European forms of phenomenology and existentialism. Scheler was clearly influenced by James and from him, a personalistic strain entered the Frankfurt School as well, and indeed, through Edith Stein, also there is a line from James to Pope John Paul II. Thus, it might not be too much to say that Royce and James exported personalism back to Europe, although the view had been perpetuated there independently within the Catholic church and from such sources as Renouvier and the remaining followers of Lotze among the neo-Kantians.

The principles of Harvard personalism may be summarized thus:

- Person (both human and non-human) is a process, moving from less personal to more personal.

- Time is real, allowing the development of person, but not ensuring it.

- Metaphysics is generalized from ethics, not a fundamental science or study.

- Practical life is the source of value and meaning in life.

- Communities are the basis of individual life, i.e., the "soul" is communal at its origin and becomes individual through a social process; the community is the "person" in the most concrete and excellent sense.

- God, or the divine, is personal to the extent we can understand and respond to deity.

- If the impersonal exists, we cannot understand it.

As with the Boston University (BU) School, one might spend a very long time on these principles, but that is not my present purpose. I would point 
out that the two schools overlap in their emphasis on the practical and the ethical, and upon certain aspects of the existence of the impersonal. But Harvard tends to explain away sin, while BU retains it. The reality of time for the Harvard philosophers, and the corresponding implications for the metaphysics of process and the nature of God, is in tension with the more traditional theism of the BU School. The Harvard School tends more toward reconciliation with naturalism, and at times its panexperientialism flirts with pantheism. In time Hartshorne came to call the view "panentheism," and the later influence of Whitehead moved process philosophers in the Harvard tradition away from personalism (although Hartshorne maintained his personalism to the end).

Perhaps the most important point of contrast is the idea that the community is the person in the highest sense, maintained by Royce, Peirce, and Hartshorne, but less by James and Hocking. In the BU School, the tendency to emphasize the individual as the most concrete and highest exemplar of person was countered by Walter G. Muelder's "social personalism," and shared by a whole generation of later BU personalists. Thus, we see a tension in both schools, Harvard because the view does not give enough weight to the individual, and $\mathrm{BU}$ because the view gives too much weight to the individual.

Obviously, there are theological implications to these differences (as well as for the similarities). The place of the individual soul in soteriorlogy, for example, moves away from standard orthodoxy for the Harvard group, and becomes a matter of post-Millenialist, Scheiermachean striving to bring about the Kingdom of God on earth. The community is the means of salvation. However, the Harvard view does have a more robust (and closer to orthodox) view of the church as the Body of Christ (the exemplary and most concrete person), and of the Trinity as a community. The Harvard group is also in a position (and Royce does this explicitly) to maintain a modified doctrine of Original Sin, the Communion of Saints, the Invisible Church, and a number of other principles central to Christian tradition.

On the other hand, the BU School is clearly Protestant, with a Pelagian view of sin (rejecting Original Sin), and a tendency to render the church and worship an unnecessary addendum to a pious life. They reject mediation between the individual soul and the divine, even in the case of Christ, since the completed work of Christ renders on-going mediation extraneous. Living the godly life, practically and individually, is the means of salvation, since the work of Christ is finished. Indeed, Bowne himself was tried for heresy 
by the Methodist Church on grounds such as these, since he did not seem to value the Scriptures highly enough and recommended a kind of salvation that required no specific doctrine or prescribed beliefs. Thus, the BU personalists embrace a number of positions that the Roman Catholic Church worked very hard to invalidate, over the centuries. Yet, the form of theism espoused by the BU School, the conception of God, is much more orthodox than that of the Harvard School. It is not easy to guess which of these two forms of personalism would be preferable to the main body of the Church, since both depart in ways that are impossible to reconcile with orthodox Christianity.

Yet, the American personalists took themselves to be doing more good than harm, both philosophically and theologically. Their effort to reconcile philosophy and theology with modern life is clear. Being unattached to particular forms of dogma, they reinvented Christianity around a view of the person, rather than adapting the modern view of the person to an older religious framework. That might be the very definition of heresy, but it did not trouble the American personalists, nor was it their aim to criticize the Church. They aimed to save what was essential in the teachings of Christianity and religion in general, and did so to the best of their ability.

\section{BIBLIOGRAPHY OF AMERICAN PERSONALISM: PRIMARY AND SECONDARY SOURCE LITTERATURE}

Auxier, Randall E. "Borden Parker Bowne." In The Dictionary of Modern American Philosophers, General Editor John Shook, 306-312. Bristol, UK: Thoemmes Press, 2005), vol. 1.

. "Bowne on Time, Evolution. and History." Journal of Speculative Philosophy 12, no. 3 (1998): 181-203.

_ . "Brightman, Edgar Sheffield." Encyclopedia Americana. Bethel, CT: Grolier Publishing Co., 2001.

_. "Brightman, Edgar Sheffield." Dictionary of Literary Biography: American Philosophers Before 1950, vol. 270, edited by Philip B. Dematteis and Leemon McHenry, 14-20. Detroit: Gale Publishing Co., 2003.

- Critical Responses to Josiah Royce, 1885-1916, 3 vols. Bristol, UK: Thoemmes Press, 2000.

"Fourth Generation Boston University Personalism: The Philosophy of Thomas O. Buford," in Personalizm: Prawda, Dobro, Piękno [Polish-English Edition] 10 (2006): 61-78. (Polish translation: Filozofia personalistyczna Thomasa Buforda by Bogusław Gacka).

"God as Catholic and Personal: A Protestant Perspective on Norris Clarke's Neo-Thomistic Personalism." International Philosophical Quarterly 40, no. 2 (2000): 235-252. 
"God, Process and Persons: Charles Hartshorne and Personalism." Process Studies 27, no. 3-4 (1998): 175-201.

"Hocking, William Ernest." In The Dictionary of Modern American Philosophers, General Editor John Shook, vol. 2, 1128-1135. Bristol, UK: Thoemmes Press, 2005.

. "Howison, George Holmes." In The Dictionary of Modern American Philosophers, General Editor John Shook, vol. 2, 1179-1185. Bristol, UK: Thoemmes Press, 2005.

. "Mysticism and the Immediacy of God: Howison's and Hocking's Critique of Royce." Personalist Forum 15, no. 1 (Spring 1999): 59-83.

"Personalism.” In Encyclopedia Americana. Bethel, CT: Grolier Publishing Co., 2003.

. "Royce, Josiah." In The Dictionary of Modern American Philosophers, General Editor John Shook, vol. 4, 2089-2096. Bristol, UK: Thoemmes Press, 2005.

. "Scheler and the Very Existence of the Impersonal." Eidos: A Journal for the Philosophy of Culture, 1, no. 3 (April 2018): 74-86. http://eidos.uw.edu.pl/files/pdf/eidos/2018-01/ eidos_3_auxier.pdf.

- Time, Will and Purpose: Living Ideas from the Philosophy of Josiah Royce. Chicago, IL: Open Court, 2013.

. "Wampum, Person, and the Life of Exchange." In The Cultural Power of Personal Objects, edited by Jared Kemling, 267-301. Albany, NY: SUNY Press, 2021.

. "Why 100 Years is Forever: Hartshorne on Immortality." Personalist Forum 14, no. 2 (Fall 1998): 109-140

Auxier, Randall E., and Mark Y.A. Davies. Hartshorne and Brightman on God, Process and Persons: The Correspondence, 1922-1945. Nashville: Vanderbilt University Press, 2001.

Bengtsson, Jan Olof. The Worldview of Personalism: Origins and Early Development. Oxford: Oxford University Press, 2006.

Bowne, Borden Parker. The Essence of Religion. Boston: Houghton Mifflin, 1910.

- The Immanence of God. Boston: Houghton Mifflin, 1905.

- Metaphysics. New York: American Book Company, 1884.

- Personalism. Boston: Houghton Mifflin, 1908.

- Theism. New York: American Book Company, 1902.

- Theory of Thought and Knowledge. New York: Harper and Brothers, 1899.

Brightman, Edgar Sheffield. Moral Laws. New York: Abingdon Press, 1933.

—. A Philosophy of Religion. Atlantic Highlands, NJ: Prentice Hall, 1940.

- Person and Reality, edited by Peter Anthony Bertocci, Jannette E. Newhall, and Robert S. Brightman. New York: Ronald Press, 1958.

. The Problem of God (New York: Abingdon Press, 1930).

Buckham, John Wright, and George Malcolm Stratton, eds. George Holmes Howison, Philosopher and Teacher. Berkeley: University of California Press, 1934.

Burrow, Rufus, Jr. A Critical Introduction to Personalism. St. Louis: Chalice Press, 1999.

- God and Human Dignity: The Personalism, Theology, and Ethics of Martin Luther King, $J r$. Notre Dame: University of Notre Dame Press, 2008.

Deats, Paul, and Carol Robb, eds. The Boston Personalist Tradition in Philosophy, Social Ethics and Theology. Macon, GA: Mercer University Press, 1986.

Clendenning, John. The Life and Thought of Josiah Royce, rev. $2^{\text {nd }}$ ed. Nashville: Vanderbilt University Press, 1999.

Flewelling, Ralph T. Christ and the Dramas of Doubt: Studies in the Problem of Evil. New York: Abingdon Press, 1913. 
- Personalism and the Problems of Philosophy. New York: Abingdon Press, 1915).

- The Reason in Faith. New York: Abingdon Press, 1924.

- Creative Personality: A Study in Philosophical Reconciliation. New York: Abingdon Press, 1926).

- The Person; or, the Significance of Man. Los Angeles: Ward-Ritchie Press, 1952.

Gacka, Bogumił. Bibilography of American Personalism. Lublin: Oficyna Wydawnicza CZAS, 1994, pp. 87-184.

- Bibliography of The Personalist, 1920-1979. Lublin: [n.n.d.].

Hocking, William E. The Meaning of God in Human Experience. New Haven, CT: Yale University Press, 1912.

- Human Nature and Its Remaking. New Haven, CT: Tale University Press, 1929.

. The Lasting Elements of Individualism. New Haven, CT: Yale University Press, 1937.

. The Self, Its Body, and Freedom. New Haven, CT: Yale University Press, 1928.

Howison, George Holmes. The Limits of Evolution and Other Essays, 2nd ed. New York: Macmillan, 1904.

James, William. The Correspondence of William James, edited by Ignas K, Skrupskelis and Elizabeth M. Berkeley, 12 vols. Charlottesville: University of Virginia Press, 1992-2004.

- Essays, Comments, and Reviews, edited by Frederick H. Burkhardt, et al. Cambridge: Harvard University Press, 1987.

—. Essays in Radical Empiricism. New York: Longmans, Green, and Co., 1912.

_. A Pluralistic Universe. Philadelphia: David McKay, 1909.

- Principles of Psychology, 2 vols. Authorized edition. New York: Dover Books, 1950 [1890]).

- The Varieties of Religious Experience. New York: Modern Library, [1902].

-Writings of William James, edited by John J. McDermott. Chicago: University of Chicago Press, 1992.

- The Works of William James: Manuscript Lectures, edited by Ignas K. Skrupskelis. Cambridge, MA / London, England: Harvard University Press, 1988.

Knudson, Albert C. The Philosophy of Personalism. New York: Abingdon Press, 1927.

Marcel, Gabriel. "The Dialectical Conditions of a Philosophy of Intuition," (1912). Translated by Dwayne A. Tunstall and Randall Auxier, Marcel Studies 2, no. 1 (2017): 36-45. https://explore. neumann.edu/hubfs/Website-PDFs/Home/Marcel\%20Studies/Dwayne-Trans2017.pdf

- Royce's Metaphysics. Translated by Virginia and Gordon Ringer. Chicago: Henry Regnery Co., 1956.

McConnell, Francis. J. Borden Parker Bowne: His Life and Philosophy. New York: Abingdon Press, 1929.

Menand, Louis. The Metaphysical Club: A Story of Ideas in America. New York: Farrar Straus and Giroux, 2001.

Muelder, Walter G. Moral Law in Christian Social Ethics. Richmond: John Knox Press, 1966.

Oppenheim, Frank M., S.J. Reverence for the Relations of Life: Re-imagining Pragmatism via Josiah Royce's Interactions with Peirce, James and Dewey. Notre Dame, IN: Notre Dame University Press, 2004).

_. Royce's Mature Ethics. Notre Dame, IN: Notre Dame University Press, 1993. 
- Royce's Mature Philosophy of Religion. Notre Dame, IN: Notre Dame University Press, 1987.

Peirce, Charles S. Writings of Charles S. Peirce: A Chronological Edition, edited by Edward C. Moore, et al., vols. 1-6, 8. Bloomington: Indiana University Press, 1982-2010.

Collected Papers of Charles Sanders Peirce, 8 vols., edited by Charles Hartshorne, Arthur W. Burks, and Paul Weiss. Cambridge: Harvard University Press, 1931-1958.

Perry, Ralph Barton. The Thought and Character of William James, 2 vols. Boston: Little, Brown and Co., 1935.

Royce, Josiah. The Conception of God: A Philosophical Discussion Concerning the Divine Idea as a Demonstrable Reality, edited by George Holmes Howison, New York: Macmillan, 1897.

- Fugitive Essays, edited by Jacob Loewenberg. Cambridge, MA: Harvard University Press, 1920.

- The Philosophy of Loyalty. New York: Macmillan, 1908.

- The Problem of Christianity, 2 vols. New York: Macmillan, 1913.

- The Religious Aspect of Philosophy. Boston: Houghton Mifflin, 1885.

. The Sources of Religious Insight. New York: Macmillan, 1912.

-The Spirit of Modern Philosophy: An Essay in the Form of Lectures. Boston: Houghton Mifflin, 1892.

- Studies of Good and Evil: A Series of Essays upon the Problems of Philosophy and of Life. New York: Macmillan, 1898.

. The World and the Individual: The Four Historical Conceptions of Being, First and Second Series. New York: Macmillan, 1899, 1901.

Shook, John R., ed. The Real Metaphysical Club: The Philosophers, Their Debates, and Selected Writings from 1870 to 1885. Albany, NY: SUNY, 2019.

Smith, John E. Royce's Social Infinite: The Community of Interpretation. New York: Philosophical Library, 1950.

Tunstall, Dwayne A. Yes, But Not Quite: Encountering Josiah Royce's Ethico-Religious Insight. New York: Fordham University Press, 2009.

\section{REFERENCES}

Anderson, Douglas R. Creativity and the Philosophy of C.S. Peirce. Dordrecht: Springer, 1987.

James, William. Manuscript Lectures, edited by Ignas K. Skrupskelis. Cambridge, MA / London, England: Harvard University Press, 1998.

James, William. Principles of Psychology, 2 vols. Authorized edition. New York: Dover Books, 1950 [1890]. 


\section{HISTORIA I ZASADY AMERYKAŃSKIEGO PERSONALIZMU: PORÓWNANIE SZKÓŁ PERSONALIZMU NA UNIWERSYTECIE HARVARDA I NA UNIWERSYTECIE W BOSTONIE}

\section{Streszczenie}

Autor przedstawia tło amerykańskiej filozofii i teologii personalistycznej, a następnie śledzi niemieckie ich korzenie zwłaszcza w dwóch głównych szkołach amerykańskiej myśli personalistycznej - na Boston University i na Harvard University. Po drodze wskazuje główne punkty dotyczące wpływów i rozbieżności w rozwoju personalizmu amerykańskiego. Podsumowuje zasady obu szkół oraz poglądy zarówno filozoficzne, jak i religijne odrzucane przez personalistów.

\section{Przektad angielskiego abstraktu} Stanistaw Sarek

Słowa kluczowe: filozofia; teologia; personalizm; amerykańska myśl personalistyczna; niemieckie korzenie; szkoła personalizmu w Boston University; szkoła personalizmu w Harvard University. 